Романюк І. В., к.т.н., доцент, Пінчук О. Л., к.т.н., доцент,

Герасімов Є. Г., к.т.н., доцент, Демянчук В. В., студент (Національний університет водного господарства та природокористування, м. Рівне)

\title{
ОСОБЛИВОСТІ КОНСТРУКЦІЇ СИСТЕМИ КРАПЕЛЬНОГО ПОЛИВУ МАЛИНИ СОРТУ «GLEN AMPLE» НА ЗЕМЛЯХ ТЗОВ «ХАРЕСС»
}

В роботі вивчений досвід використання крапельного поливу при вирощуванні малини сорту «GLEN AMPLE». Застосування стрічки «Ro-Drip» в системах поливу сільськогосподарських культур дозволяє знизити експлуатаційні витрати, а також підвищити якість продукції і урожайність, що виключно важливо в умовах високої конкуренції на українському ринку. Стрічка «Ro-Drip» дає можливість, крім поливу, вносити необхідні добавки і хімічні речовини 3 меншими втратами і великою довготерміновою економією. Ніяка інша крапельна стрічка не $є$ такою дослідженою і випробуваною в реальних умовах експлуатації. Вона задовольняється усім вимогам щодо по стійкості до засмічення і довговічності, що пред'являються високоефективним системам крапельного зрошення.

Ключові слова: краплинне зрошення, системи поливу, економічні ефективність, стрічка «Ro-Drip», експлуатація.

Взагалі про малину вперше стало відомо з древніх рукописів, написаних ще в 3 столітті до н. е., які свідчать про те, що наші предки збирали в лісі ягоди і вживали їх у їжу. Масово малина почала культивуватися на заході Європи в 16 столітті н. е. Завдяки старанням сучасних селекціонерів, з лісової малини з'явилося безліч сортів, які вирощуються практично в кожному саду на території України [1].

На землях, що орендуються ТзОВ «ХАРЕСс» була висаджена малина сорту «Glen Ample», який має шотландське походження виведений в 1996 році шляхом схрещування сорту Глен Прозен і Мекер. Малина сорту «Glen Ample» - це смачний середньостиглий сорт найбільш популярний і вирощуваний у Європі з дуже високою врожайністю.

Агротехніка вирощування цієї ягоди надзвичайно проста, вона не вибаглива у догляді, відрізняється незрівнянним ароматом і приємними смаковими якостями. Для посадки малини були вибрані ок- 
ремі ділянки далеко від тіні, оскільки від кількості сонячного світла залежить успішність її плодоношення. Грунт підходить практично будь-який, не виносить вона заболочених місцевостей і ділянок з високим заляганням підземних вод. Суглинні і піщані ґрунти можна збагатити чорноземом або дерновою землею, торфом. Однак, як показує досвід, малина може давати врожай і на бідних ґрунтах.

Правильні і необхідні заходи по догляду - це регулярні поливи, прополка бур'янів, розпушування ґрунту, підживлення і обрізка. Малина досить вибаглива до умов зволоження, тому продуктивність плантації залежить від своєчасного та достатнього забезпечення рослин водою.

Найбільше вологи малина потребує в період цвітіння та достигання ягід, коли значна вегетативна маса рослин витрачає на транспірацію до 5-8 мм води щодня.

Рослини мають поверхнево розміщену кореневу систему, і тому в змозі ефективно використовувати запаси вологи в ґрунті лише 3 глибини 0-0,5 м. Ці запаси визначаються вологоутримуючою здатністю ґрунту - ґрунти з легким механічним складом та низьким вмістом органічної речовини (піщані та супіщані) можуть утримувати лише 40-50 мм вологи, тоді як важкі ґрунти - до 100 мм. Зрошення варто розпочинати тоді, коли рослини ще не проявляють ознаки дефіциту вологи - оптимальним часом для поливу є зниження вмісту вологи у грунті до 70\% НВ. Тому виходячи з вище викладено було використано для поливу крапельне зрошення [4].

Крапельне зрошення застосовується в овочівництві в промислових масштабах в Україні з 1997 року. Позитивні результати на всіх сільськогосподарських культурах і на всіх типах грунтів сприяли динамічному розвитку цього способу зрошення. Успіх в застосуванні крапельного зрошення радикально змінив сучасний підхід до комплексу «вода-грунт-рослина», на фоні дозованого режиму живлення, і сприяв новому підходу в області зрошення взагалі.

Крапельне зрошення - це метод найбільш раціональний з точки зору використання води, потребує не такого потужного джерела водопостачання, як спринклерне зрошення, менш енергоємний, дозволяє вносити водорозчинні добрива при фертигації та інсектициди для боротьби з ґрунтовими шкідниками, проте вода має бути очищеною від механічних та біологічних домішок задля уникнення блокування системи водовипусків [5].

Малина сорту «Glen Ample» на землях, що орендуються ТзОВ «XАРECс» була висаджена на ділянці площею 16 га, яка розташова- 
на в чотирьох секторах. Система крапельного поливу, що застосована для поливу малини складається з магістрального трубопроводу діаметром 110 мм та розподільчого трубопроводів діаметром 75 мм, а також із крапельної стрічки «Ro-Drip».

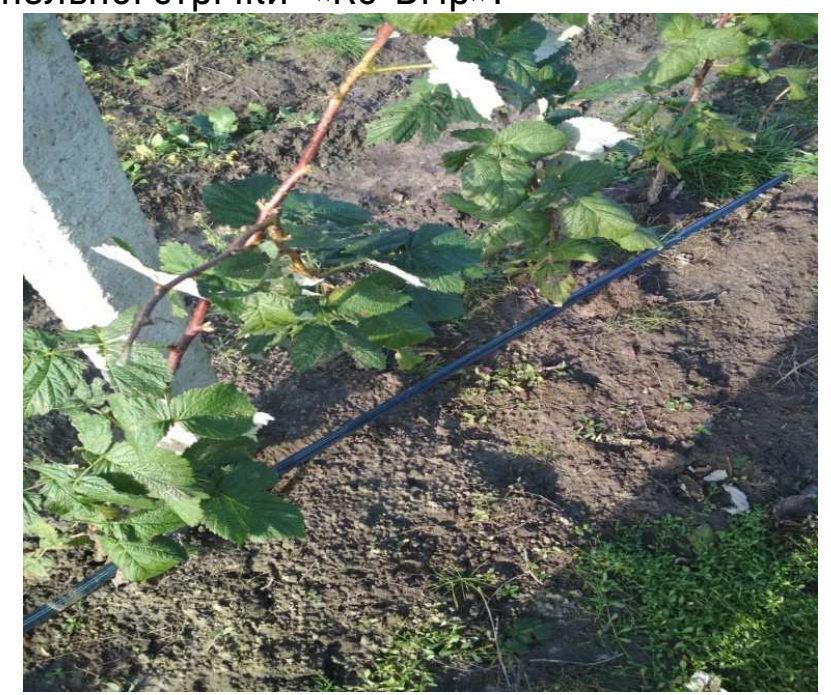

Фото 1. Малина сорту «Glen Ample» при крапельному поливі

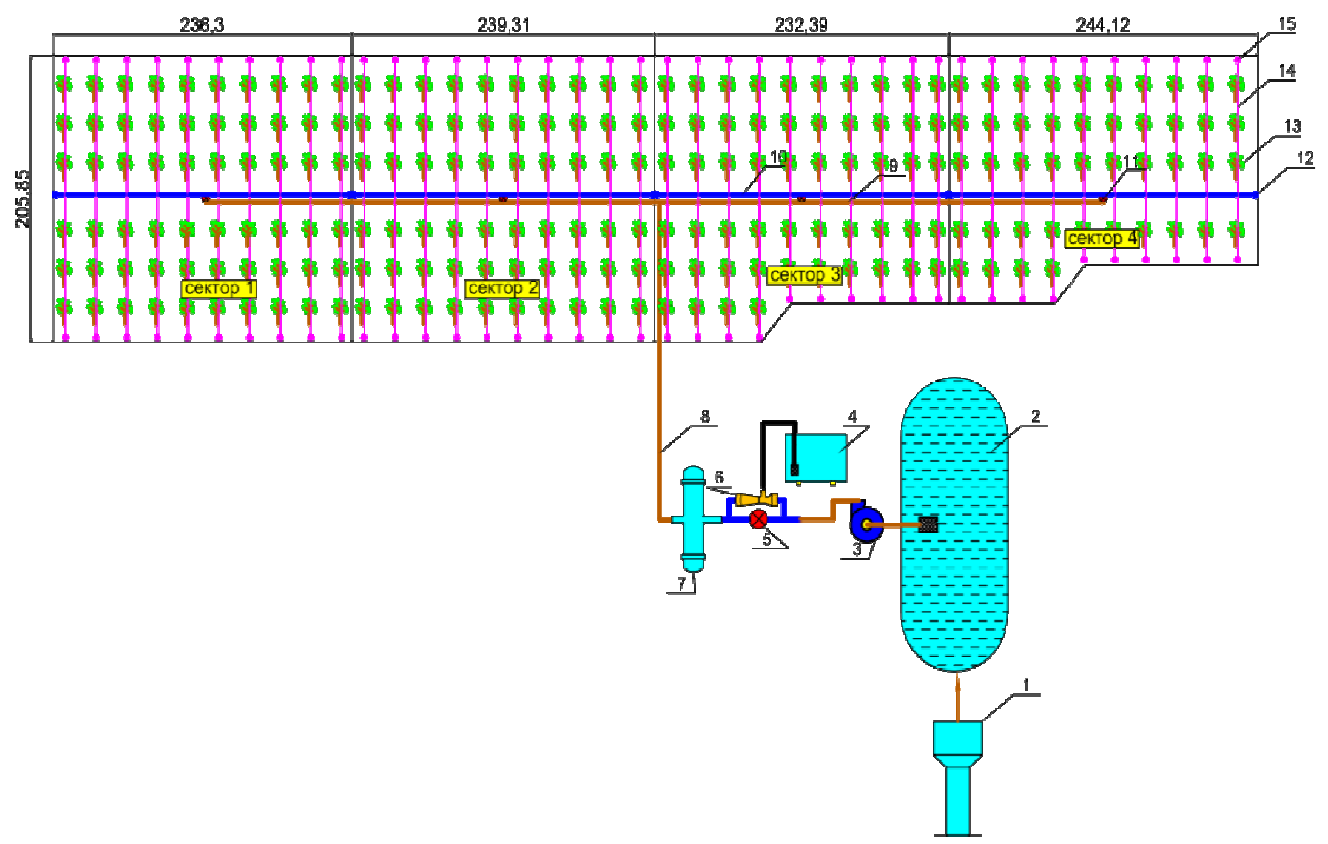

Рис. 1. План-схема ділянки крапельного поливу малини:

1 - свердловина; 2 - басейн; 3 - насос; 4 - підживлююча ємність; 5 - засувка; 6 - інжектор; 7 - фільтр; 8 - магістральний трубопровід; 9, 10 - розподільчий трубопровід; 12, 15 - заглушка; 13 - кущ малини; 14 - крапельна стрічка «Ro-Drip» 
Як видно з рис. 1, системи крапельного поливу складається 3:

$\checkmark$ джерела водопостачання;

$\checkmark$ вузла підготовки і внесення добрив;

$\checkmark$ фільтростанції;

$\checkmark$ магістральних та розподільчих трубопроводів;

$\checkmark$ регуляторів тиску, сполучної та запірної фурнітури.

Додатково система може містити вузли автоматичного контролю та управління системою, а також обліку витрати води.

Джерелом водопостачання є свердловина з якої здійснюється забір води. Свердловина була пробурена ТОВ «ГЕОЛОГ ЛТГ» глибиною 95,0 м, робочим діаметром 93 мм і дебітом 5,4 м³/год, а також закріплена обсадними трубами. Експлуатаційними показниками свердловини $є$ статистичний тиск, що становить 5,0 м, динамічний 16,0 м при дебіті 5,4 м³/год. Відповідно до експлуатаційних рекомендацій було встановлено насос потужністю $6,0 \mathrm{~m}^{3} /$ год. Глибину установки насоса можна змінювати у залежності від обсягу водоподачі, але не нижче 22,0 м [3]. Виходячи із рекомендацій було використано чотирьохтактну бензинову мотопомпу TM «Könner\&Söhnen» 3 діаметром вхідної труби 80 мм. Вода яка забиралася із свердловини подавалася до заспокійливого басейну, який має розміри 60×20 м. Вода надійшовши до басейну відстоювалася та нагрівалася, а потім за допомогою аналогічної мотопомпи подавалася до системи крапельного поливу попередньо пройшовши фільтр очистки.

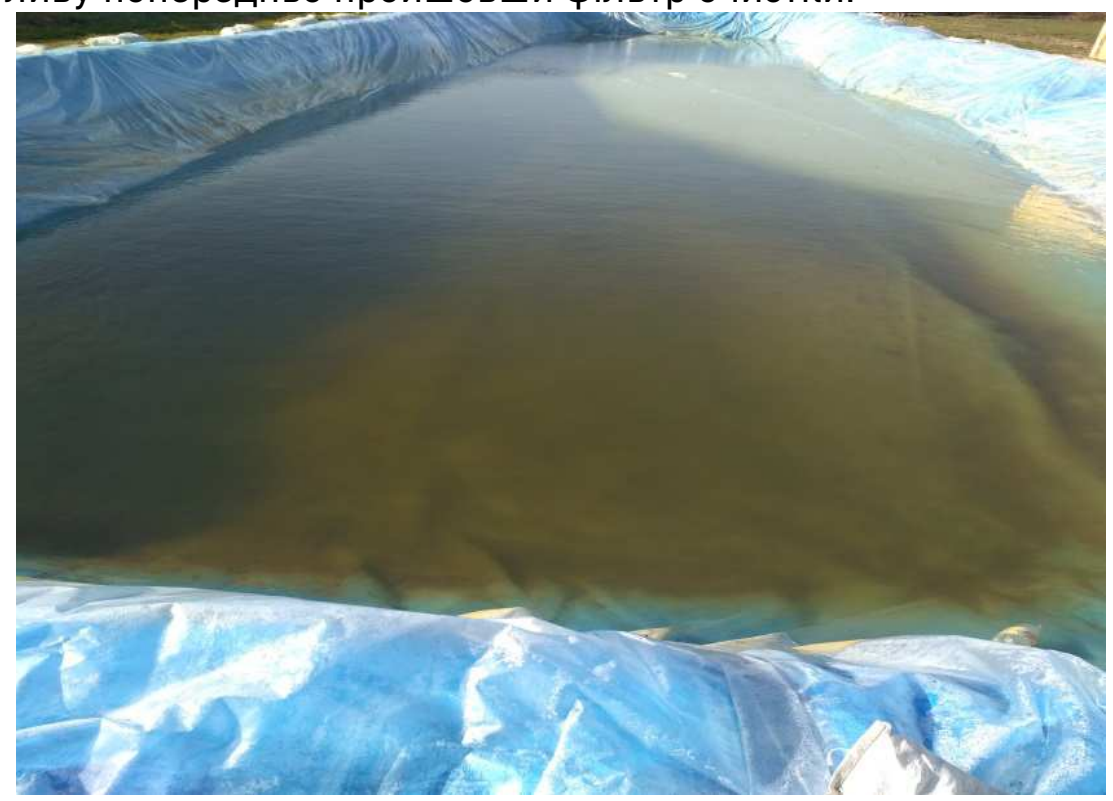

Фото 2. Басейн-відстійник 
Один з найважливіших елементів системи є фільтраційна станція. Вона призначена для доведення якості води до встановлених параметрів. Залежно від наявності у воді певних домішок і величини зрошуваної площі, фільтраційна станція може включати сітчасті, дискові, гравійні фільтри, гідроциклони або їх комбінації.

В нашому випадку було підібрано дисковий фільтр. Конструкція дискового фільтру призначена для більш глибокого фільтрування. Складається 3 корпусу і фільтруючого елемента у вигляді набору щільно стиснутих тонких дисків з радіальними канавками. Вони поєднують надійність і найменшу собівартість обслуговування. Використовуються для видалення неорганічних і органічних частинок. Зазвичай використовуються при заборі води з свердловин. При засміченні можуть промиватися зворотним потоком води. Ступінь фільтрації 20-50-100-125 micron, площа фільтрації - 1805 см², максимальний робочий тиск -8 bar, максимальна пропускна здатність: $50 \mathrm{~m}^{3} /$ год.

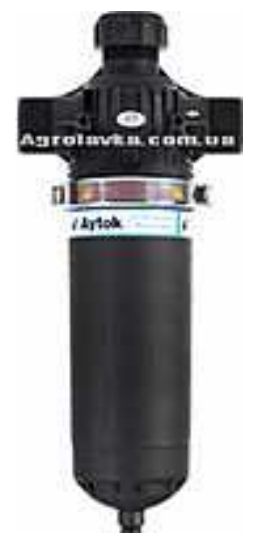

Фото 3. Дисковий фільтр для фільтрації води в системі крапельного поливу

Вузол внесення добрив або підживлююча ємність призначені для дозованого внесення добрив разом з поливною водою. Може складатися з удобрювальної головки та інжектора або дозатрона, а також ємності для приготування розчину добрив.

Зрошувальні трубки - крапельні лінії, що укладаються паралельно одна одній, згідно з технологією, і з'єднані з поперечною магістраллю трубопроводу. Емітери - краплинні зволожувачі (крапельниці) скріплені з трубопроводом або складові з ним єдине ціле, в залежності від конструкції. їх призначення - дозований випуск води 3 трубопроводу в невеликих кількостях. 


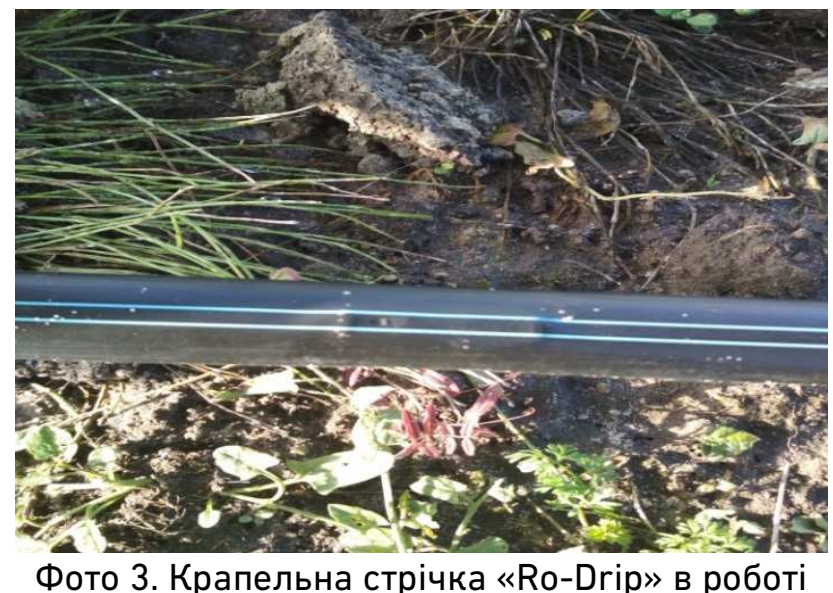

Крапельна стрічка «Ro-Drip» забезпечує найбільше надійне і ефективне вирішення будь-яких зрошувальних задач при підземному і поверхневому зрошенні навіть при довжині стрічки, яка перевищує 400 метрів. Стрічка «Ro-Drip» - $є$ диною крапельною стрічкою, спеціально розробленою для забезпечення рівномірного потоку і дозволяє вирішити одну із самих складних проблем в експлуатації засмічення в умовах сильного забруднення.

Висока якість поліетилену зі стійкістю проти ультрафіолетових випромінювань. Крапельна стрічка «Ro-Drip» - надійне та економічно найбільш ефективне рішення з представлених сьогодні на українському ринку.

Виробляється з застосуванням надійних сучасних технологій, які й зробили компанію John Deere Water світовим лідером з високоточних систем подачі води. Крапельна стрічка «Ro-Drip» підходить як для надземного, так і для підземного зрошення [6]. Спроектована для підтримання постійної швидкості потоку води й вирішення найбільш складної проблеми, з якою в наш час стикаються сільгоспвиробники, - проблеми блокування потоку води в умовах високої забрудненості.

RO-DRIP має три запатентовані незалежні системи протидії засміченню:

- Точно сформований канал (фото 4). Висока точність проектування ґарантує переріз каналу 140 мікрон прямокутної форми - більший, ніж у будь-якої іншої системи крапельного зрошення, що пропонуються на ринку України. Це забезпечує найбільшу стійкість проти засмічування. При цьому дотримується однорідність усіх каналів. Кожний контур системи крапельного зрошення спроектовано та сформовано так, щоб усунути нерівномірність поливу та забезпечити 
стабільну швидкість водного потоку.

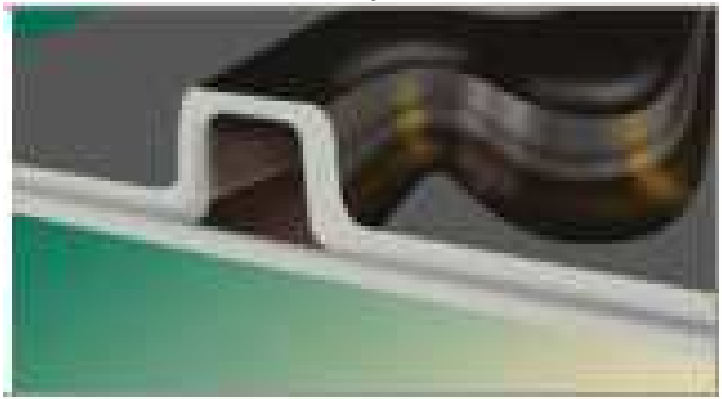

Фото 4. Прецизійна форма каналу

- Турбулентний потік (Vortex Flow Action) - протидіє засміченню системи шляхом призупинення руху рідини (фото 5). Турбулентний рух рідини в системі крапельного зрошення призупиняє частки бруду, сприяє подоланню кутів, викривлень і поворотів каналу. У результаті тверді частки безперервно вимиваються потоком води й не можуть закупорити канал.

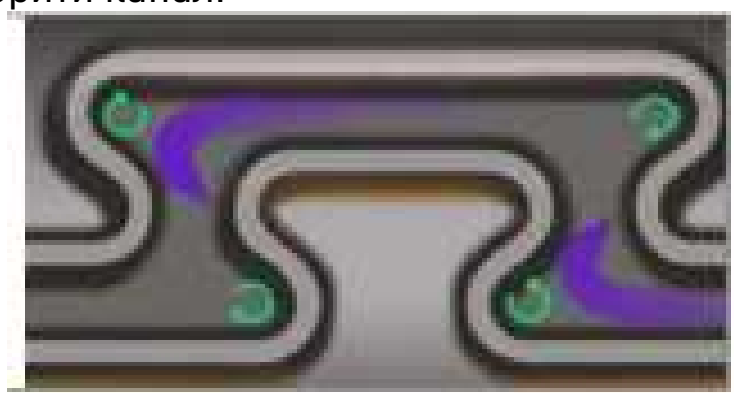

Фото 5. Система Vortex Flow Action

- Промивний канал, що розширюється (фото 6). За екстремальних умов фільтрації води або відсутності фільтрації використовують унікальну технологію каналу, що розширюється (Expanding Flow Channel).

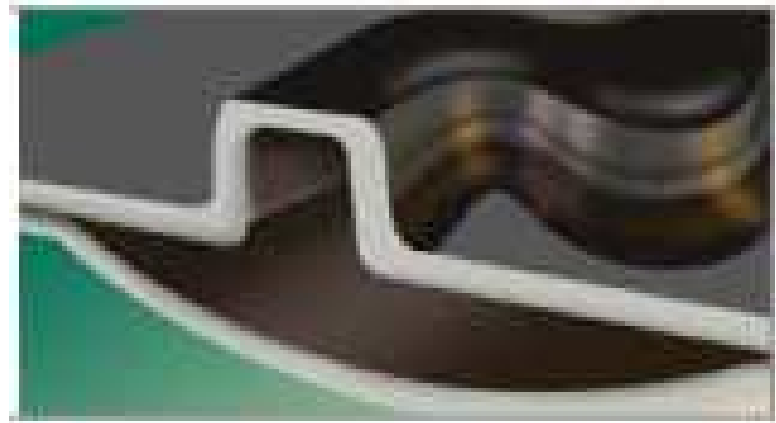

Фото 6. Додатковий захисний канал 
Технологія полягає в зміні форми каналу при блокуванні пропускного каналу крапельниці, що дає змогу видалити навіть найбільш щільні скупчення макрочасток. Канал може тимчасово розширюватися, аби перешкоду можна було знищити, а потік рідини відновити. Ця унікальна особливість «Ro-Drip» створює додатковий захист проти засмічення в умовах високого засміченості.

Застосування стрічки «Ro-Drip» в системах поливу сільськогосподарських культур дозволяє знизити експлуатаційні витрати, а також підвищити якість продукції і урожайність, що виключно важливо в умовах високої конкуренції на українському ринку. Стрічка «RoDrip» дає можливість, крім поливу, вносити необхідні добавки і хімічні речовини з меншими втратами і великою довготерміновою економією. Ніяка інша крапельна стрічка не $є$ такою дослідженою і випробуваною в реальних умовах експлуатації. Вона задовольняється усім вимогам щодо по стійкості до засмічення і довговічності, що пред'являються високоефективним системам крапельного зрошення. Неперевершена якість, простота монтажу і демонтажу, спрощена структура і зниження затрат на вирощування урожаю роблять стрічку «Ro-Drip» лідером по експлуатаційним характеристикам для польових зрошувальних систем любої довжини. Наприкінці вегетації зрошення не здійснюють тому, що це може призвести до надмірного вегетативного росту та, як результат, зниження зимостійкості плантації.

1. Малина звичайна. URL: http://uk.wikipedia.org/wiki/Малина_Звичайна (дата звернення: 22.11.2018). 2. Касіянчук В. Д., Касіянчук М. В. Малина як цінна продовольча культура і лікарська культура. Вип. 10-12. 2013. Агроінком. С. 8-9. 3. Паспорт гідрогеологічної свердловини № 1/17. Складений згідно технічних умов проектування і спорудження бурових свердловин на воду БН-14-57. Ковель, 2017. 4. URL: http://dachni-rady.com/malina/93.html (дата звернення: 10.11.2018). 5. Ромашенко М. І., Балюк С. А. Зрошення земель в Україні. Стан та шляхи поліпшення. Видавництво світ. 2000. 110 с. 6. URL: http://agrimatco.by/kapelnaya-lenta-ro-drip/ (дата звернення: 10.11.2018).

\section{REFERENCES:}

1. Malyna zvychaina. URL: http://uk.wikipedia.org/wiki/Malyna_Zvychaina (data zvernennia: 22.11.2018). 2. Kasiianchuk V. D., Kasiianchuk M. V. Malyna yak tsinna prodovolcha kultura i likarska kultura. Vyp. 10-12. 2013. Ahroinkom. S. 8-9. 3. Pasport hidroheolohichnoi sverdlovyny № 1/17. Skladenyi zghidno tekhnichnykh umov proektuvannia i sporudzhennia burovykh 
sverdlovyn na vodu BN-14-57. Kovel, 2017. 4. URL: http://dachnirady.com/malina/93.html (data zvernennia: 10.11.2018). 5. Romashenko M. I., Baliuk S. A. Zroshennia zemel v Ukraini. Stan ta shliakhy polipshennia. Vydavnytstvo svit. 2000.110 s. 6. URL: http://agrimatco.by/kapelnaya-lenta-ro-drip/ (data zvernennia: 10.11.2018).

Рецензент: д.Т.н., професор Ткачук М. М. (НУВГП)

Romaniuk I. V., Candidate of Engineering (Ph.D.), Associate Professor, Pinchuk 0. L., Candidate of Engineering (Ph.D.), Associate Professor, Herasimov I. H., Candidate of Engineering (Ph.D.), Associate Professor, Demianchuk V. V., Senior Student (National University of Water and Environmental Engineering, Rivne)

CONSTRUCTION PECULIARITIES OF DROP IIRRIGATION SYSTEM OF THE RASPBERRY "GLEN AMPLE" ON THE TERRYTORY OF LLC "HARESS"

The experience of using drip irrigation during the cultivation of raspberry varieties "GLEN AMPLE" has been studied. Application of the ribbon "Ro-Drip" in irrigation systems of agricultural crops can reduce operating costs, as well as improve product quality and yield, which is extremely important in conditions of high competition in the Ukrainian market. The ribbon "Ro-Drip" makes it possible, in addition to watering, to add necessary additives and chemicals with less losses and a long-term saving. No other drip band is tested and tested under actual operating conditions. It is satisfied with all the requirements for the resistance to clogging and longevity imposed on highly effective drip irrigation systems.

Keywords: drip irrigation, irrigation systems, economic efficiency, "RoDrip" tape, operation.

Романюк И. В., к.т.н., доцент, Пинчук О. Л., к.т.н., доцент, Герасимов Е. Г., к.т.н., доцент, Демянчук В. В., студент

(Национальный университет водного хозяйства и природопользования, г. Ровно)

ОСОБЕННОСТИ КОНСТРУКЦИИ СИСТЕМЫ КАПЕЛЬНОГО ПОЛИВА МАЛИНЫ СОРТА «GLEN AMPLE» НА ЗЕМЛЕ 000 «ХАРЕСс» 
В работе изучен опыт использования капельного полива при выращивании малины сорта «GLEN AMPLE». Применение ленты «Ro-Drip» в системах полива сельскохозяйственных культур позволяет снизить эксплуатационные расходы, а также повысить качество продукции и урожайность, что исключительно важно в условиях высокой конкуренции на украинском рынке. Лента «RoDrip» дает возможность, кроме полива, вносить необходимые добавки и химические вещества с меньшими потерями и большой долгосрочной экономией. Никакая другая капельная лента не является исследованной и испытанной в реальных условиях эксплуатации. Она удовлетворяется всем требованиям по устойчивости к засорению и долговечности, предъявляемым высокоэффективным системам капельного орошения.

Ключевые слова: капельное орошение, системы полива, экономические эффективность, лента «Ro-Drip», эксплуатация. 